\title{
Pengembangan Modul Pembelajaran Kontekstual disertai Concept Mapping pada Materi Elastisitas dan Hukum Hooke
}

\section{${ }^{1}$ Laxmi Zahara, ${ }^{2}$ Fartina, ${ }^{3}$ Khaerus Syahidi, ${ }^{4}$ Hikmatul Qudsiah}

${ }^{1}$ Prodi Pendidikan Fisika, FMIPA, Universitas Hamzanwadi, Jln. TGKH. Muhammad Zainuddin Abdul Madjid No. 132 Pancor Selong, Lombok Timur, NTB, 83611

Email Korespondensi: laxmizahara3@gmail.com

\begin{tabular}{|c|c|}
\hline Article Info & Abstract \\
\hline $\begin{array}{l}\text { Article History } \\
\text { Received: } 13 \text { Nov } 2021 \\
\text { Revised: } 13 \text { Dec } 2021 \\
\text { Published: } 30 \text { Dec } 2021 \\
\text { Keywords } \\
\text { Contextual, Concept } \\
\text { Mapping, Module }\end{array}$ & $\begin{array}{l}\text { This research aims to develop and determine the quality of the contextual } \\
\text { learning module accompanied by a concept mapping of elasticity material and } \\
\text { law Hooke in class XI IPA MA Mu'allimat NW Pancor students. This type of } \\
\text { research is research and development. The method used in this research is } 4-D \\
\text { method, which consists of the stages of define, design, development and } \\
\text { dissemination. This research is limited to the stage, development namely the } \\
\text { development test on a limited scale. The data in this study were analyzed } \\
\text { descriptively qualitatively. The research subjects included } 3 \text { lecturers and } 3 \\
\text { physics teachers as validators, and students of class XI IPA } 1 \text { MA Mu'allimat } \\
\text { NW Pancor as respondents. The validation of lecturers and physics teachers } \\
\text { both resulted in a score of } 3.85 \text { and the development trial on a limited scale } \\
\text { resulted in a score of } 3.88 \text {. All research results indicate that the module is } \\
\text { feasible to be developed. }\end{array}$ \\
\hline Informasi Artikel & Abstrak \\
\hline $\begin{array}{l}\text { Sejarah Artikel } \\
\text { Diterima: } 13 \text { Nov } 2021 \\
\text { Direvisi: } 13 \text { Des } 2021 \\
\text { Dipublikasi: } 30 \text { Des } 2021 \\
\text { Kata kunci } \\
\text { Kontekstual, Concept } \\
\text { Mapping, Modul }\end{array}$ & $\begin{array}{l}\text { Penelitian ini bertujuan untuk mengembangkan dan mengetahui kualitas } \\
\text { modul pembelajaran kontekstual disertai concept mapping materi elastisitas } \\
\text { dan Hukum Hooke pada siswa kelas XI IPA MA Mu'allimat NW Pancor. Jenis } \\
\text { penelitian ini yaitu penelitian dan pengembangan/research and development. } \\
\text { Metode yang digunakan pada penelitian ini yaitu metode 4-D, yang terdiri dari } \\
\text { tahapan define, design, development dan dissemination. Penelitian ini dibatasi } \\
\text { hingga tahap development yaitu uji pengembangan pada skala terbatas. Data } \\
\text { dalam penelitian ini dianalisis secara deskriptif kualitatif. Subjek penelitian } \\
\text { meliputi } 3 \text { dosen dan } 3 \text { guru fisika sebagai validator, serta siswa kelas XI IPA } \\
1 \mathrm{MA} \text { Mu'allimat NW Pancor sebagai responden. Validasi dosen dan guru } \\
\text { fisika sama-sama menghasilkan skor 3,85 dan uji coba pengembangan pada } \\
\text { skala terbatas menghasilkan skor 3,88. Semua hasil penelitian menunjukkan } \\
\text { bahwa modul layak untuk dikembangkan. }\end{array}$ \\
\hline
\end{tabular}

Sitasi: Zahara, L., Fartina, F., Syahidi, K., \& Qudsiah, H. (2021), Pengembangan Modul Pembelajaran Kontekstual disertai Concept Mapping pada Materi Elastisitas dan Hukum Hooke, Kappa Journal. 5(2), 183190

\section{PENDAHULUAN}

Pendidikan merupakan salah satu dinamo penggerak bangsa. Semakin baik kualitas pendidikan yang diselenggarakan oleh suatu bangsa, maka akan semakin baik pula kualitas bangsa tersebut. Tahap perencanaan pembelajaran meliputi penyusunan rencana pelaksanaan pembelajaran, penyiapan media dan sumber belajar, perangkat penilaian pembelajaran dan skenario pembelajaran. Hal tersebut diatur dalam Peraturan Menteri Pendidikan dan Kebudayaan nomor 22 tahun 2016 tentang Standar Proses Pendidikan Dasar dan Menengah. 
Penyiapan media dan sumber belajar menjadi salah satu poin penting dalam perencanaan. Sumber belajar adalah segala sesuatu, baik benda maupun orang yang mampu memberikan pemahaman dan pengajaran tentang suatu hal tertentu. Sejalan dengan itu (Abdul Majid, 2012) menyatakan bahwa sumber belajar tidak terbatas bentuknya bisa berupa cetakan seperti buku, video, bahkan orang dan lingkungan sekitar yang mampu memberikan informasi berguna bagi peningkatan pengetahuan siswa.

Sumber belajar sering kali tersedia di hadapan peserta didik, namun belum optimal dimanfaatkan untuk kepentingan pendidikan (Muktiono Waspodo. 2012). Semakin tersedianya sumber belajar di lingkungan sekitar, memberi peluang dan kesempatan untuk melakukan kegiatan belajar. Namun, sesuatu dikatakan sumber belajar jika mampu memberi makna bagi peserta didik. Salah satu bahan ajar yang mampu memberikan makna bagi peserta didik adalah modul. Menurut (Abdul Majid, 2012) Modul menjadi bermakna jika peserta didik dapat menggunakannya dengan mudah. Ilustrasi yang ditampilkan dalam modul disesuaikan dengan pengalaman peserta didik sehingga mudah untuk dipelajari.

Fisika adalah ilmu dasar yang dekat dengan kehidupan siswa. Fisika merupakan ilmu yang mempelajari tentang berbagai fenomena atau gejala alam dan seluruh interaksi yang ada di dalamnya. Karena konsep fisika yang bersifat abstrak menyebabkan banyak siswa kesulitan dalam memahami dan memaknai pembelajran fisika. Hal ini juga berdampak pada minat yang rendah terhadap pelajaran fisika. Untuk mengoptimalkan hasil siswa maka dibutuhkan sumber belajar yang tepat. Menurut (Moh Juaini, 2019) Fisika akan lebih bermakna jika terdapat kesinambungan antara materi pembelajaran dengan lingkungan tempat tinggal yang dijadikan sebagai media dan sumber belajar. Salah satu cara yang dapat dilakukan adalah dengan mengintegrasikan apa yang ada dilingkungan tempat tinggal siswa ke dalam bahan ajar fisika.

Selama ini, penggunaan bahan ajar masih dominan menggunakan buku-buku teks dari pemerintah. Seperti yang terlihat di MA Mu'allimat NW Pancor. Bahan ajar yang digunakan berupa buku PR dan buku-buku teks dari pemerintah yang memiliki cakupan materi yang rumit. Untuk mengatasi masalah tersebut, sebagian guru mulai merancang bahan ajar baru berupa modul pembelajaran sebagai penunjang keberhasilan pembelajaran. Akan tetapi modul yang dibuat guru masih memiliki kekurangan, seperti: tampilan kurang menarik sehingga siswa kurang termotivasi dalam membaca dan mempelajarinya; memuat lebih banyak soal-soal daripada penjelasan materi sehingga menimbulkan banyak pertanyaan jika digunakan dalam pembelajaran mandiri; modul tersebut lebih menekankan pada kemampuan siswa dalam menjawab soal, bukan memahami konsep. Kekurangan pada bahan ajar ini berdampak pada menurunnya kemampuan siswa dalam memahami konsep.

Berdasarkan latar belakang masalah diatas, peneliti tertarik untuk mengembangan sebuah modul fisika kontekstual disertai concept mapping. Tujuan pengembangan ini sendiri adalah untuk menghasilkan bahan ajar berupa modul kontekstual yang bisa membantu siswa dalam memahami kaitan antara pembelajaran fisika dengan pengalaman sehari-hari siswa. Selain itu concept mapping pada modul ditampilkan pada setiap awal penjelasan materi untuk menyederhanakan dan mengarahkan materi pembelajaran, sehingga memudahkan siswa menggunakannya belajar secara mandiri. Modul dibuat semenarik mungkin dengan mengarahkan kegiatan praktikum dalam modul menggunakan aplikasi PhET (Physics Education Of Thechnology) sehingga menambah keterampilan siswa dalam penggunaan teknologi.

\section{METODE}

Jenis penelitian ini adalah pengembangan karena menghasilkan sebuah produk. Adapun produk yang dihasilkan dalam penelitian ini yaitu bahan ajar fisika berupa modul pembelajaran kontekstual disertai concept mapping pada materi elastisitas dan hukum Hooke. 
Metode yang digunakan pada penelitian ini adalah metode penelitian dan pengembangan (R\&D) mengacu pada model 4-D (four-D). Model ini diperkenalkan oleh Thiagarajan pada 1974. Model ini terdiri dari empat tahapan, yaitu: define, design, development dan dissemination. Tahap define (pendefinisian), berisi kegiatan pengumpulan data realita sebanyak mungkin terkait dengan berbagai permasalahan, kelemahan atau suatu yang menjadi pendorong untuk menetapkan produk apa yang akan dikembangkan beserta spesifikasinya. (Fatrima Santri S, 2018) Kegiatan pada masing-masing tahapan akan diuraikan sebagai berikut:1) Define (pendefinisian); 2) Design (perancangan); 3) Rancangan ini disebut draft I; 3) draft II

Subjek dalam penelitian dan pengembangan ini adalah 15 orang siswa kelas XI IPA 1 MA Mu'allimat NW Pancor, sedangkan objek dalam penelitian dan pengembangan ini berupa angket validasi dosen ahli materi, guru fisika dan angket respon siswa. Penelitian ini dilaksanakan pada bulan Agustus di MA Mu'allimat NW Pancor pada tahun pelajaran 2020/2021. Penelitian ini merupakan penelitian pengembangan, maka data yang akan diperoleh adalah data primer, yaitu data tentang kualitas modul yang dikembangkan. Data yang dikumpulkan berupa hasil validasi dari ahli materi, dan guru mata pelajaran. Data tersebut meliputi penilaian dari aspek kelayakan isi, kebahasaan, penyajian dan kegrafisan yang berupa kritik dan saran.

Instrumen yang digunakan dalam penelitian dan pengembangan ini terdiri dari Lembar Validasi dan Angket Respon. Secara garis besar, pekerjaan analisis data meliputi 3 langkah, yaitu: 1) Tabulasi data yang diperoleh dari para validator untuk setiap komponen dari butiran penilaian yang tersedia dalam instrumen penilaian; 2) Menghitung skor rata-rata dari setiap komponen dengan menggunakan rumus:

$$
\bar{x}=\frac{\sum x}{n}
$$

Keterangan:

$$
\begin{aligned}
\bar{x} & =\text { skor rata }- \text { rata } \\
\sum_{n} x & =\text { jumlah skor } \\
& =\text { jumlah responden }
\end{aligned}
$$

1. Membandingkan nilai rata-rata total skor masing-masing komponen dengan kriteria dari skala lima, sebagai berikut:

Tabel 1. Kriteria Skor Rata-Rata

\begin{tabular}{ccccc}
\hline No & Rentang skor & & Nilai & Kategori \\
\hline 1. & $X>x_{i}+1,8 \mathrm{Sbi}$ & $>4,2$ & $\mathrm{~A}$ & Sangat baik \\
\hline 2. & $x_{i}+0,6 \mathrm{Sbi}<X \leq x_{i}+1.8 \mathrm{Sbi}$ & $>3,4-4,2$ & $\mathrm{~B}$ & Baik \\
\hline 3. & $x_{i}-0,6 \mathrm{Sbi}<X \leq x_{i}+0.6 \mathrm{Sbi}$ & $>2,6-3,4$ & $\mathrm{C}$ & Cukup Baik \\
\hline 4. & $x_{i}-1,8 \mathrm{Sbi}<X \leq x_{i}-0,6 \mathrm{Sbi}$ & $>1,8-2,6$ & $\mathrm{D}$ & Kurang Baik \\
\hline 5. & $X \leq x_{i}-1,8 \mathrm{Sbi}$ & $\leq 1,8$ & $\mathrm{E}$ & $\begin{array}{c}\text { Sangat Kurang } \\
\text { Baik }\end{array}$ \\
\hline
\end{tabular}

Keterangan:

$X=$ Skor empiris

$x_{i}=$ rerata ideal $=\frac{1}{2}$ (skor maksimal ideal + skor minimal ideal $)$

Sbi $=$ Simpangan baku ideal 


$$
=\frac{1}{6}(\text { skor maksimal ideal }- \text { skor minimal ideal })
$$

\section{HASIL DAN PEMBAHASAN}

\section{A. Hasil Penelitian}

Berdasarkan penelitian dan pengembangan yang dilakukan, diperoleh hasil penelitian sebagai berikut:

1. Hasil Define (Pendefinisian)

Pada tahap ini dilakukan penggalian informasi terkait dengan permasalahan dan akar pendorong dilakukannya pengembangan suatu produk serta analisis terhadap kebutuhan siswa.

\section{Hasil Design (Perancangan)}

Pada tahap ini dilakukan perancangan terhadap produk yang akan dikembangkan yaitu modul pembelajaran kontekstual disertai concept mapping. Desain layout isi modul disusun untuk mempermudah siswa memahami maksud dari isi modul. Beberapa penyusunan layout pada modul ini antara lain pemilihan font yang berbeda antara judul dengan penjelasan materi. Background dibuat sedemikian rupa dengan lebih berwarna agar siswa lebih termotivasi untuk belajar menggunakan modul tersebut. Pada bagian atas background ditampilkan judul materi dengan tambahan gambar ilustrasi slinky dog (litned.co.uk) untuk materi elastisitas dan gambar susunan pegas (RumusHitung.com) untuk materi hukum Hooke. Lembar awal pada setiap sub bab dilengkapi dengan indikator-indikator pembelajaran serta penjelasan materi dibantu dengan penambahan gambar ilustrasi. Setiap awal penjelasan materi pada sub bab ditampilkan concept mapping agar alur pikiran siswa lebih terarah. Bagian isi modul terbagi menjadi 2 sub bab yaitu Elastisitas Zat Padat dan Hukum Hooke. Bagian isi dari modul ini juga dilengkapi dengan bagian evaluasi berupa penugasan, lembar kegiatan siswa dan uji kompetensi. Selain itu, disisipkan juga pengaplikasian fisika dan tokoh fisikawan yang berhubungan dengan konsep pada modul.

Desain komponen pendukung modul disusun sedemikian rupa untuk menarik minat pengguna dalam mempelajari modul. Komponen-komponen pendukung modul antara lain: abstraksi, petunjuk penggunaan modul, standar isi, daftar isi, peta konsep, glosarium dan daftar pustaka. Perancangan instrumen lembar angket respon siswa. Lembar angket siswa digunakan untuk mendapatkan informasi mengenai respon siswa terhadap modul pembelajaran kontekstual disertai concept mapping dalam kegiatan pembelajaran.

3. Hasil Development (Pengembangan)

Pada Tahap ini, produk divalidasi oleh dosen ahli materi, guru fisika dan siswa untuk menilai tingkat kelayakan modul. Berikut data hasil validasi yang didapatkan:

1) Data Hasil Validasi Dosen Ahli Materi dan Guru Fisika

Pada tahap ini, peneliti menggunakan 3 orang dosen pendidikan Fisika Universitas Hamzanwadi.

Validasi dilakukan dengan memberikan modul yang telah dikembangkan kepada para ahli beserta angket penilaian yang berisi beberapa aspek penilaian, yaitu kelayakan isi, kebahasaan, penyajian dan kegrafisan. Selanjutnya para ahli melakukan penilaian dengan mengisi indikator-indikator untuk masing-masing aspek yang terdapat pada angket penilaian. Berikut data hasil validasi modul pembelajaran kontekstual disertai concept mapping' Validasi dari dosen ahli materi menghasilkan skor 3,85 (X>3,4), sehingga masuk dalam kategori baik dan mendapatkan nilai B. Berdasarkan nilai tersebut, maka modul dapat dikatakan layak untuk diuji cobakan.

2) Data Hasil Validasi Guru Fisika

Pada tahap ini, peneliti menggunakan 3 orang guru Fisika dari 3 sekolah. Daftar guru fisika yaitu \}: 1) Khairul Kaspiani, S.Pd (Guru Fisika MA Mu'allimat NW Pancor); 2) Lalu Gede 
Sudarman, S.Pd (Guru Fisika SMAN 2 Masbagik) dan 3) Muslihatin Jalilah (Guru Fisika SMK GRL). Validasi dilakukan dengan memberikan modul yang telah dikembangkan kepada para guru Fisika beserta angket penilaian yang berisi aspek penilaian dan indikator-indikator yang sama dengan dosen ahli, yaitu kelayakan isi, kebahasaan, penyajian dan kegrafisan. Selanjutnya para guru Fisika melakukan penilaian dengan mengisi indikator-indikator untuk masingmasing aspek yang terdapat pada angket penilaian.

Penilaian dari guru Fisika menghasilkan skor 3,85 (X>3,4), sehingga masuk dalam kategori baik dan mendapatkan nilai B. Berdasarkan nilai tersebut, maka modul dapat dikatakan layak untuk diuji cobakan.

3) Data Hasil Uji Pengembangan (Skala terbatas)

Pada tahap ini, peneliti menggunakan 15 orang siswa kelas XI IPA 1 MA Mu'allimat NW Pancor. Penilaian respon siswa menghasilkan skor 3,88 (X>3,4), sehingga masuk dalam kategori baik dan mendapatkan nilai B. Berdasarkan nilai tersebut, maka modul dapat dikatakan layak untuk diuji cobakan pada skala yang lebih besar. Akan tetapi penelitian ini hanya dibatasi pada uji pengembangan pada skala terbatas dan tidak melalui tahap uji coba skala besar.

\section{B. Pembahasan}

Penelitian pengembangan modul pembelajaran kontekstual disertai concept mapping ini menggunakan model pengembangan 4D yang dibatasi hanya sampai pada tahap development. Tahap yang dilalui pada penelitian ini yaitu, define (pendefinisian), design ( perancangan) dan development (pengembangan). Pada tahap pengembangan peneliti tidak melalui tahap uji coba skala besar. Hal ini dikarenakan penyebaran COVID19 yang berpengaruh terhadap proses pembelajaran di sekolah. Penelitian ini sama dengan penelitian yang dilakukan oleh SN Fitriani (2017) dengan judul Pengembangan Modul Fisika Berbasis Sets Untuk Memberdayakan Kemampuan Berpikir Kritis Siswa, yaitu modul dinilai berdasarkan kelayakan materi, media, dan bahasa, serta uji coba (terbatas dan kelompok besar) kepada siswa, dan tahap penyebaran pada Guru Fisika. Bedanya pada penelitian yang dilakukan sampai uji coba skala terbatas.

Sebelum diuji cobakan, modul terlebih dahulu melalui proses pendefinisian. Pada tahap ini peneliti melakukan kegiatan menemukan permasalahan, kelemahan atau suatu kondisi yang menjadi akar pendorong kegiatan pengembangan atas suatu produk. Tahap pendefinisian diawali dengan analisis awal akhir sampai spesifikasi tujuan. a) Analisis awal akhir, pada tahap ini peneliti mempelajari masalah yang dihadapi guru dalam menentukan alternatif bahan ajar yang lebih efektif; b) Analisis konsep yakni analisis materi dengan cara mengidentifikasi materi utama yang perlu diajarkan; c) Analisis tugas, dilakukan untuk mengidentifikasi keterampilan-keterampilan yang diperlukan pada proses pembelajaran. Analisis tugas digunakan untuk merinci isi materi ajar dalam bentuk garis-garis besar isi materi; d) Spesifikasi tujuan, yakni melakukan perumusan indikator pencapaian kompetensi ke dalam tujuan pembelajaran.

Selanjutnya tahap pendesainan, pada tahap ini dilakukan perancangan modul yang akan dikembangkan yakni modul pembelajaran kontekstual disertai concept mapping; a) penyusunan tes instrumen yang digunakan untuk menilai kelayakan dan keefektifan modul yang dikembangkan (instrumen validasi); b) Pemilihan media yang sesuai tujuan, untuk menyampaikan materi pembelajaran; c) Pemilihan format pengembangan modul, yakni mendesain isi pembelajaran, pemilihan pendekatan, dan sumber belajar, mengorganisasikan dan merancang isi modul, membuat desain modul yang meliputi desain layout, gambar dan tulisan. Peneliti mendesain modul semenarik mungkin agar siswa termotivasi membacanya dan mempelajarinya; 4) Rancangan awal yang telah dibuat oleh peneliti kemudian diberi masukan oleh dosen pembimbing. Masukan tersebut digunakan untuk memperbaiki modul. Kemudian melakukan revisi setelah mendapat saran perbaikan dari dosen pembimbing dan nantinya rancangan ini akan dilakukan tahap validasi. 
Selanjutnya tahap pengembangan, pada tahap ini sebelum modul diuji cobakan terlebih dahulu divalidasi oleh 3 dosen ahli dan 3 guru fisika. Cara ini sama dengan penelitian yang dilakukan oleh Zulfawati dkk (2021), dengan penelitian yang berjudul Pengembangan Kemampuan Berpikir Kritis Peserta Didik SMA dengan Lembar Kerja Proses pada Mata Pelajaran Fisika yaitu Validasi melibatkan 7 validator yang terdiri dari dosen ahli dan pendidik yang bersangkutan. Hasil validasi oleh dosen ahli dan guru fisika sama-sama mendapatkan skor 3,85. Skor ini menunjukkan kualitas modul dikategorikan baik sehingga layak untuk dikembangkan. Validasi dosen ahli tidak hanya mendapatkan data skor penilaian saja tetapi juga kritik dan saran. Kritik dan saran tersebut dijadikan acuan perbaikan terhadap rancangan awal modul, Selanjutnya, setelah dilakukan revisi berdasarkan kritik dan saran dari dosen ahli dan guru fisika, dilakukan penilaian oleh siswa. Penilaian dari siswa dilakukan dengan subjek yang terbatas yaitu 15 orang siswa. Hasil penilaian pada tahap ini mendapatkan skor 3,88. Hasil tersebut menunjukkan bahwa modul layak untuk dikembangkan.

Hasil perolehan skor pada tahap uji coba terbatas mengalami kenaikan skor 0,03 jika dibandingkan dengan penilaian dosen ahli dan guru fisika. Kenaikan ini dikarenakan sebelum dilakukan uji coba telah dilakukan perbaikan terhadap modul sesuai dengan masukan dan saran dari dosen ahli dan guru fisika. Perbedaan skor pada masing-masing tahap tidak menunjukkan perubahan yang signifikan. Hasil penilaian validasi dosen ahli, guru fisika dan respon siswa menunjukkan bahwa produk pengembangan layak digunakan dalam proses pembelajaran. Walaupun dinyatakan "layak" namun masukan-masukan yang diberikan oleh dosen ahli, guru fisika dan siswa dapat digunakan. Hasil penelitian ini sesuai dengan penelitian yang dilakukan oleh Kiki Andila (2021) , dengan judul Pengembagan E-Modul Berbasis Kontekstual Menggunakan Aplikasi eXeLearning Pada Materi Usaha dan Energi, yaitu Bahan Ajar berbentuk emodul dinyatakan layak digunakan oleh ahli media dengan persertase $75 \%$, hasil validasi ahli materi pertama dan kedua dengan persentase 76,2\% dengan kriteria layak digunakan, validasi ahli pembelajaran dengan persentase $82 \%$ dengan katergori layak digunakan.

\section{KESIMPULAN}

\section{A. Kesimpulan Tentang Produk}

Berdasarkan data hasil penelitian dan pembahasan dapat disimpulkan beberapa hal sebagai berikut: 1) Modul pembelajaran yang dihasilkan pada penelitian ini telah dinilai valid/layak yang dilihat dari hasil penilaian dosen ahli dan guru fisika. Penilaiannya samasama mendapatkan rata-rata skor 3,85 yang berada pada rentang skor >3,4-4,2 dengan kategori "baik". Oleh karena itu bahan ajar yang dihasilkan layak digunakan untuk memperoleh data pada uji coba pengembangan; 2) Berdasarkan hasil respon siswa pada uji coba pengembangan dengan jumlah subjek yang terbatas diperoleh skor rata-rata 3,88 yang berada pada rentang skor $>3,4-4,2$ dengan kategori "baik". Oleh karena itu bahan ajar yang dihasilkan layak digunakan dalam pembelajaran; 3) Berdasarkan penilaian dosen ahli, guru fisika dan respon siswa modul pembelajaran ini "layak" digunakan.

\section{SARAN}

Berdasarkan kesimpulan dan keterbatasan penelitian, peneliti sarankan:1) Perlu dilakukan uji coba pemakaian dan revisi modul sebelum pengembangan pada tahap dissemination; 2) Modul pembelajaran ini diharapkan dapat disebarluaskan secara umum di sekolah-sekolah khususnya di tingkat SMA/MA; 3) Guru diharapkan memanfaatkan modul pembelajaran ini dalam menyampaikan materi elastisitas dan Hukum Hooke untuk siswa SMA/MA kelas XI IPA; 4) Diharapkan adanya pengembangan kembali terhadap modul pembelajaran ini dan muncul lebih banyak lagi modul pembelajaran yang berbeda. 


\section{DAFTAR PUSTAKA}

Anonim. 2015. Pemanfaatan Elastisitas Pada Sepeda Motor. Diunduh di http://fisikachakim.blogspot.om/2015/12/pemanfaatan-elastisitas-padasepeda.html?,=1 pada tanggal 28 Maret 2020.

BSNP. 2014. Instrumen Penilaian Buku Teks Pelajaran Tahun 2014. Diunduh di https://bsnp-indonesia.org/ategory/evaluasi-buku/ pada 14 Maret 2020.

Chasanah, Risdiyani, Dara Nurani \& Adip Ma'rifu Sururi. 2017. Fisika Peminatan dan IlmuIlmu Alam. Klaten: PT Intan Pariwara.

Depdiknas. 2008. Penulisan Modul. Jakarta: Direktorat Tenaga Kependidikan , Dirjen Peningkatan Mutu Pendidikan dan Tenaga Kependidikan, Depdiknas.

Dudi Indrajit.2009. Mudah dan Aktif Belajar Fisika. Jakarta: Pusat Perbukuan Departemen Pendidikan Nasional..

Dwisetyaningrum, Yulia. 2017. Modul Fisika Part 1 Elastisitas dan Hukum Hooke. Diunduh di

https://www.academia.edu/39229111/Modul_Fisika_part_1_Elastisitas_dan_Hukum_ Hooke pada tanggal 27 Mei 2020.

Hamzah, Amir. 2019. Metode Penelitian \& Pengembangan (Research \& Development) Uji Produk Kuantitatif dan Kualitatif Proses dan Hasil Dilengkapi Contoh Proposal Pengembangan Desain Uji Kualitatif dan Kuantitatif. Malang: CV Literasi Nusantara Abadi.

Husamah dkk. 2016. Belajar \& Pembelajaran. Malang: Universitas Muhammadiyah Malang. Jaya, Sang Putu Sri. 2018. Elastisitas. Diunduh di https://fisikakontekstual.com/materielastisitas pada 28 Mei 2020.

Juaini, Moh. 2019. Pengembangan Modul Pembelajaran Fisika Berbasis Kontekstual Pada Materi Dinamika Rotasi dan Kesetimbangan Benda Tegar. Kappa Journal Volume 3 Nomor 1. Selong: Program Studi Pendidikan Fisika Universitas Hamzanwadi.

Kanginan, Marthen. 2013. Fisika Untuk SMA Kelas X. Jakarta: Erlangga.

Kiki Andila, dkk. 2021. Pengembagan E-Modul Berbasis Kontekstual Menggunakan Aplikasi eXeLearning Pada Materi Usaha dan Energi. Kappa Journal. Desember 2021. Vol. 5, No. 1. https://e-journal.hamzanwadi.ac.id/index.php/kpj/article/view/2757

Komalasari, Kokom (Ed). 2013. Pembelajaran Kontekstual Konsep dan Aplikasi. Bandung: PT Refika Aditama.

Majid, Abdul (Ed). 2012. Perencanaan Pembelajaran Mengembangkan Standar Kompetensi Guru. Bandung: PT Remaja Rosdakarya.

Mudlofir, Ali. 2011. Aplikasi Pengembangan Kurikulum Tingkat Satuan Pendidikan (KTSP) dan Bahan Ajar Dalam Pendidikan Agama Islam. Jakarta: PT Raja Grafindo Persada.

Mulyono. 2012. Strategi Pembelajaran Menuju Efektivitas Pembelajaran di Abad Global. Malang: UIN Maliki Press (Anggota IKAPI).

Munthe, Bermawy. 2011. Desain Pembelajaran. Yogyakarta: Pustaka Insan Madani.

Prasetyo, Eko (Ed). 2015. Ternyata Penelitian Itu Mudah (Panduan Melaksanakan Penelitian Bidang Pendidikan). Lumajang: Penerbit eduNomi.

Prastowo, Andi (Ed). 2015. Panduan Kreatif Membuat Bahan Ajar Inovatif. Jogjakarta: DIVA Press (Anggota IKAPI).

Rahayu, Siti Dwi. 2017. Pengembangan Modul Fisika Berbasis Concept Mapping Pada Materi Elastisitas di SMA. Jurnal Pembelajaran Fisika Volume 6 Nomor 3. Jember: Universitas Jember. 
Rusman. 2014. Model-Model Pembelajaran Mengembangkan Profesional Guru. Jakarta: PT Raja Grafindo Persada.

Sa'ud, Udin Syaefudin (Ed). 2017. Inovasi Pendidikan. Bandung: CV Alfabeta.

SN Fitriani. 2017. Pengembangan Modul Fisika Berbasis Sets Untuk Memberdayakan Kemampuan $\begin{array}{lllllll}\text { Berpikir Kritis Siswa. Vol } 1, \quad \text { No } 2017) . & \text { https://e- }\end{array}$ journal.hamzanwadi.ac.id/index.php/kpj/article/view/Fitriani

Sugiyanto (Ed). 2010. Model-Model Pembelajaran Inovatif. Surakarta: Yuna Pustaka bekerja sama dengan FKIP UNS Surakarta.

Sugiyono. 2014. Metode Penelitian Kuantitatif Kualitatif dan R\&D. Bandung: CV Afabeta.

Sutarti, Tatik, Edi Irawan (Ed). 2017. Kiat Sukses Meraih Hibah Penelitian Pengembangan. Yogyakarta: Depublish.

Syafri, Fatrima Santri (Ed). 2018. Pengembangan Modul Pembelajaran Aljabar Elementer Di Program Studi Tadris Matematika IAIN Bengkulu. Bengkulu: CV Zigie Utama.

Trianto (Ed). 2008. Mendesain Pembelajaran Kontekstual (Contextual Teaching And Learning) di Kelas. Jakarta: Cerdas Pustaka Publisher.

Ummah, Desita Solikhatul. 2019. Pengembangan Modul Pembelajaran Kontekstual Disertai Concept Mapping Untuk Meningkatkan Kemampuan Berpikir Kritis Siswa SMA. Seminar Nasional Pendidikan Fisika 2018 Volume 3 Nomor 2. Jember: Universitas Jember.

Waspodo, Muktiono. 2012. Pembelajaran Berbasis Aneka Sumber. Diunduh di http://mwsinergi.blogspot.com/2012/04/normal-0-false-false-false-en-us-Xnone.html?m=1, pada tanggal 30 September 2020.

Widoyoko, Eko Putro. 2011. Evaluasi Program Pembelajaran Panduan Praktis Bagi Pendidik dan Calon Pendidik. Yogyakarta: Pustaka Belajar.

Zulfawati, dkk. 2021. Pengembangan Kemampuan Berpikir Kritis Peserta Didik SMA dengan Lembar Kerja Proses pada Mata Pelajaran Fisika. Kappa Journal. Juni 2021. Vol. 5, No. 1. https://e-journal.hamzanwadi.ac.id/index.php/kpj/article/view/3371. 